\title{
Analysis of Student Perceptions about Online Lectures In terms of Student Learning Styles: Study of the Covid-19 Pandemic
}

\author{
W Wahidaturrahmi* \\ Mathematics Education \\ University of Mataram \\ Mataram, Indonesia \\ wahidaturrahmi@unram.ac.id
}

\author{
Mega Puspita Sari \\ Early Childhood Education \\ University of Mataram \\ Mataram, Indonesia \\ megapuspita149@gmail.com
}

\author{
Laila Hayati \\ Mathematics Education \\ University of Mataram \\ Mataram, Indonesia \\ lailahayati.fkip@unram.ac.id
}

\author{
Eka Kurniawan \\ Mathematics Education \\ University of Mataram \\ Mataram, Indonesia \\ ekakurniawan2892@unram.ac.id
}

\author{
Fitri Puji Astria \\ Early Childhood Education \\ University of Mataram \\ Mataram, Indonesia \\ fitripujia@unram.ac.id
}

\begin{abstract}
The purpose of this study was to determine students' perceptions regarding online lectures carried out during the Covid-19 pandemic in terms of student learning styles. This research is quantitative research where the population is students of the Teacher Training and Education Faculty, Mataram University. Purposive sampling is taken as a sampling technique, namely techniques that are carried out with certain considerations. Perception data collection techniques and learning styles are by distributing questionnaires via google form. The results showed that most students have good perceptions about online lectures and there is no difference in perceptions related to online lectures between students with visual, auditory, and kinaesthetic learning styles.
\end{abstract}

Keywords—online lectures, learning styles, e-learning

\section{INTRODUCTION}

In early 2020 , the corona-virus or covid-19 outbreak entered Indonesia, where the emergence of the coronavirus was first detected in China. Since then, various countermeasures have been carried out by the Government of Indonesia to reduce the impact of the Covid-19 outbreak in various sectors, especially the education sector [1]. The government through the Ministry of Education and Culture issued Circular Number 4 of 2020 concerning the Implementation of Education Policies in an Emergency for the Spread of Corona Virus Disease (Covid-19) where the learning process is carried out from home through online learning. The home learning program is applied at various levels of education in Indonesia, including in universities. Activities Teaching and learning, which was initially carried out face-to-face, were eliminated to avoid physical contact and maintain distance from others so that teaching and learning activities were carried out remotely using online media or known as online lectures.

Online lectures have become a demand in the world of education in the last few years, not only due to the Covid-19 outbreak [2]. Moreover, online education has developed well throughout the world due to the invention of new technology and global adoption of the internet, where online education will become mainstream in 2025 [3]. So that online lectures will continue, not only as an option for implementing learning due to the epidemic, but also an option in the era of technological developments that are going digital.

As a question from several parties, are students ready to carry out online lectures? Some students gave positive responses and supported the implementation of online lectures[4], [5]. However, not a few also consider face-toface lectures in class to be more effective than online lectures due to various obstacles [6],[7].

Good assessment of students towards online lectures provides a big role in the implementation of learning. The better the student's assessment, the more enthusiastic the students will be in learning and attending lectures. The assessment in question is none other than the student's perception of online lectures, where the assessment is included in the perception indicator [8]. Perception is a process of one's experience of an event or object which begins with the sensing process [9]. However, the process does not just stop, but the stimulus is continued and the next process is a perceptual process. Therefore the sensing process cannot be separated from the perceptual process, and the sensing process is a preliminary process of the perceptual process. The perception of the stimulus can come from outside, but can also come from within the individual himself. Because perception is an activity that is integrated with the individual, then what is in the individual will actively participate in the perception. So that perceptions can be expressed because feelings, thinking abilities, individual experiences are not the same, so in perceiving a stimulus,

Online lectures are expected not to reduce students' understanding in receiving teaching materials. But it needs to be realized that the implementation of online lectures has several obstacles and complaints from students. General complaints are the lack of internet network, the lack of availability of online learning tools (such as laptops), and the atmosphere of the house and the environment that is not conducive to online lectures. The biggest difficulty experienced by students is the level of understanding of the material because the learning style of each student affects the 
level of understanding in the absorption of learning material [10]. So that learning styles include support in the learning process as a form of student adaptation in facing certain strategies in online lectures. Learning style refers to the student's preferred way of learning. In reality, a person's learning style is a combination of several learning styles which are divided into three, namely: visual learning styles, auditory learning styles, and kinesthetic learning styles [11]. And each student has a different learning style that will influence him in understanding something [12]. The ability of a student to absorb and understand lessons during online lectures varies with the levels of the fast, medium, and even slow depending on their respective learning styles [13]. This indicates that students learn using the easiest way to receive, absorb and understand information during online lectures. and kinesthetic learning styles [11]. And each student has a different learning style that will influence him in understanding something [12]. The ability of a student to absorb and understand lessons during online lectures varies with the levels of the fast, medium, and even slow depending on their respective learning styles [13]. This indicates that students learn using the easiest way to receive, absorb and understand information during online lectures. and kinesthetic learning styles [11]. And each student has a different learning style that will influence him in understanding something [12]. The ability of a student to absorb and understand lessons during online lectures varies with the levels of the fast, medium, and even slow depending on their respective learning styles [13]. This indicates that students learn using the easiest way to receive, absorb and understand information during online lectures.

Starting from this background, this study aims to determine students' perceptions regarding online lectures which are differentiated based on auditory and kinaesthetic visual learning styles. By knowing the perceptions of online lectures on each student's learning style, it is hoped that it will provide an overview of future online lectures to be able to take advantage of the learning styles that are more popular by students to produce better output.

\section{METHODS}

This study is quantitative research. The population of this study was students of the Teacher Training and Education Faculty, Mataram University. With a sample of 129 students, where the sampling technique used purposive sampling. The sample taken is a sample based on the consideration that it is true that the sample conducts online lectures in two directions using teleconference media. The instrument used to collect data was a questionnaire, namely, a student perception questionnaire about online lectures consisting of 18 question items and a student learning style questionnaire consisting of 30 question items, with each questionnaire using 4 Likert scales. Questionnaires are given to students online because they are currently in a pandemic which does not allow them to collect time,

The indicators of student perceptions regarding online lectures are 1) Preparation for taking online lectures; 2) Participation in online lectures; 3) Sharing of study time during online lectures; 4) Frequency of doing online assignments; 5) Take notes and understand online teaching materials; 6) Overcoming online difficulties and 7) Assessing lectures online. While the indicators for each learning style are 1) Visual learning styles, namely learning by visual means; understand well about positions, shapes, numbers, and colors; neat and tidy; not bothered by fuss; difficulty accepting verbal instructions; 2) Auditory learning styles, namely learning by listening; good in oral activity; easily distracted by noise; weak to visual activity; 3) kinesthetic learning style, namely learning through physical activity; sensitive to expressions and body language; physically oriented and mobile; likes trial and error; weak in visual activity.

The data analysis technique in this study is divided into two, namely descriptive and inferential. The descriptive analysis technique used in this study is through the calculation of the mean (Mi) and standard deviation (Sdi). With the results of the Mi and Sdi calculations, the students' perceptions of online lectures are categorized in the following table

\section{TABLE I. CONVERSION OF STUdENT PERCEPTION SCORE}

\begin{tabular}{|c|c|}
\hline Perception Category & Score $(\mathbf{X})$ \\
\hline Very good & $\mathrm{X}>\mathrm{Mi}+\mathrm{Sdi}$ \\
\hline Good & $\mathrm{Mi}<\mathrm{X} \leq \mathrm{Mi}+\mathrm{Sdi}$ \\
\hline Pretty good & $\mathrm{Mi}-\mathrm{Sdi}<\mathrm{X} \leq \mathrm{Mi}$ \\
\hline Not good & $\mathrm{X} \leq \mathrm{Mi}-\mathrm{Sdi}$ \\
\hline
\end{tabular}

The inferential analysis uses one-way analysis of variance tools. Students' perceptions about online lectures are the dependent variable, while student learning styles are a factor that is divided into three levels of factors, namely visual, auditory and kinesthetic learning styles. The prerequisite test for one-way analysis of variance is normality (Kolmogorov-Smirnov Test) and homogeneity (Levene's Test). The alternative hypothesis proposed is that there are differences in student perceptions regarding online lectures based on learning styles

\section{RESULTS AND DISCUSSION}

\section{A. Findings}

\section{Descriptive Analysis}

Based on data analysis and categorization of student perceptions about online lectures in table 1 , the following results were obtained

\section{TABLE II. STUDENT PERCEPTION SCORE}

\begin{tabular}{|c|c|c|}
\hline Perception Category & Number of Students & Percentage (\%) \\
\hline Very good & 22 & 17 \\
\hline Good & 90 & 70 \\
\hline Pretty good & 17 & 13 \\
\hline Not good & 0 & 0 \\
\hline
\end{tabular}

In table 2 above, most students have good perceptions regarding online lectures.

The categorization of perceptions based on the type of learning style is shown in the following table

\section{TABLE III. STUDENT PERCEPTION SCORE BASED ON} LEARNING STYLE 


\begin{tabular}{|c|c|c|c|c|c|c|}
\multirow{2}{*}{$\begin{array}{c}\text { Perception } \\
\text { Category }\end{array}$} & $\begin{array}{c}\text { Number } \\
\text { of } \\
\text { Students }\end{array}$ & $\begin{array}{c}\text { Percentage } \\
(\%)\end{array}$ & $\begin{array}{c}\text { Number } \\
\text { of } \\
\text { Students }\end{array}$ & $\begin{array}{c}\text { Percentage } \\
(\%)\end{array}$ & $\begin{array}{c}\text { Number } \\
\text { of } \\
\text { Students }\end{array}$ & $\begin{array}{c}\text { Percentage } \\
(\%)\end{array}$ \\
\hline $\begin{array}{c}\text { Very } \\
\text { good }\end{array}$ & 7 & 23 & 9 & 12 & 6 & 25 \\
\hline Good & 20 & 67 & 55 & 73 & 15 & 63 \\
\hline $\begin{array}{c}\text { Pretty } \\
\text { good }\end{array}$ & 3 & 10 & 11 & 15 & 3 & 13 \\
\hline $\begin{array}{c}\text { Not } \\
\text { good }\end{array}$ & 0 & 0 & 0 & 0 & 0 & 0 \\
\hline
\end{tabular}

Most students with a tendency to visual, auditory, and kinesthetic learning styles have good perceptions regarding online lectures.

\section{Inferential Analysis}

One-way analysis of variance is included in parametric statistics so it is necessary to test for normality first

TABLE IV. NORMALITY TEST

\begin{tabular}{|c|c|c|c|}
\hline \multicolumn{2}{|c|}{ Learning Style } & Statistics & Sig. \\
\hline \multirow{3}{*}{ Data } & Visual & 0.941 & 0.099 \\
\cline { 2 - 4 } & Audio & 0.985 & 0.527 \\
\cline { 2 - 4 } & Kinesthetic & 0.931 & 0.100 \\
\hline
\end{tabular}

Based on table 1, the Sig. > 0.05 so it can be concluded that the data comes from a population that is normally distributed.

Likewise with the homogeneity test to test the similarity of the variance of each group.

\section{TABLE V. . HOMOGENEITY TEST}

\begin{tabular}{|c|c|c|}
\hline Data & Levene Statistics & Sig. \\
\hline Learning Style & 1,786 & 0.172 \\
\hline
\end{tabular}

Based on table 2, the Sig. $>0.05$ so it can be concluded that the data variance is homogeneous.

Furthermore, a one-way analysis of variance was carried out with the following output

TABLE VI. . . F-TEST ANAVA TABLE

\begin{tabular}{|c|c|c|c|c|c|}
\hline & $\begin{array}{c}\text { Sum of } \\
\text { Squares }\end{array}$ & Df & $\begin{array}{c}\text { Mean } \\
\text { Square }\end{array}$ & F & Sig. \\
\hline $\begin{array}{c}\text { Between } \\
\text { Groups }\end{array}$ & 60,956 & 2 & 30,478 & 0.956 & 0.387 \\
\hline Within Groups & 4015,013 & 126 & 31,865 & & \\
\hline Total & 4075,969 & 128 & & & \\
\hline
\end{tabular}

In the Anava table above, the Sig value is obtained. 0.387 which is greater than 0.05 , so the alternative hypothesis is rejected, which means that the mean perception score of students with visual, auditory, and kinesthetic learning styles is the same.

\section{B. Discussion}

Students' perceptions about online lectures during the Covid-19 pandemic, most of them had good perceptions, a few had very good and good perceptions, and there were no students who had bad perceptions. Like it or not, like it or not, students have to carry out lectures online because of the pandemic, even though sometimes the internet network is less stable. The Indonesian government through the Ministry of Education and Culture provides internet quota assistance to students during online lectures so that students with financial constraints can conduct online lectures. Several elearning platforms from both universities have been launched and are continuously being upgraded for the smooth running of the online lecture process, as well as other learning applications such as google classroom, Social networking features such as Whatsapp Group are quite attractive to students in online lectures [4], [14][15][16]. No less interesting is the platform offered by teleconference such as zoom, google meet, cisco webex, where students and lecturers can communicate online in two directions. Because most students have a good perception of online lectures, it could be that in the future blended learning is a form of learning that collaborates online lectures with face-to-face lectures in class[5], [17].

Likewise for students with visual, auditory, and kinesthetic learning styles, have good perceptions regarding online lectures. This indicates that all types of learning styles can well follow online lectures. And it can be interpreted that there is no better learning style, be it visual, auditory or kinesthetic because, in fact, the three learning styles are the same. However, what makes the difference depends on how a student learns and uses the learning style they like optimally. So that this will have an impact on better learning outcomes. This is reinforced by a theory which states that "if you are familiar with your learning style, you can take important steps to help yourself learn faster and easier".

Advanced testing, namely inferential statistical testing with one-way analysis of variance tools, requires that the data comes from a normally distributed population and the variance of student perceptual data related to online lectures has a homogeneous nature. The two prerequisites have been fulfilled and the analysis can be continued by testing the average similarity of students' perceptions about online lectures with visual, auditory, and kinesthetic learning styles. The results show that students' perceptions of online lectures have the same average perception score.

Both descriptively and inference lead to the same point, namely that students' perceptions of online lectures do not affect the learning styles adopted by students. Based on the responses from students, most students are aware of their responsibilities as students in studying and carry out learning independently without having to rely on lecturers' explanations and discussions with their friends. With online lectures, they can access course material anywhere and anytime with various sources on the internet. There are even those who argue that with lectures that are held online there is no need to pay for accommodation, both in renting a place to live (for students who live far from campus) and fuel for vehicles to campus. Not a few also think negatively about online lectures. But broadly speaking, students receive lectures that are carried out online with several existing obstacles, and self-awareness is needed from students to optimize learning in a way that is considered easy in absorbing course material taught online. 


\section{CONCLUSION}

Based on the results of the study, it can be concluded that most students have good perceptions regarding online lectures carried out during the Covid-19 pandemic. Visual, auditory, and cosmetic learning styles have the same perception regarding online lectures. Because most students have good perceptions regarding online lectures, it could be that in the future blended learning is carried out as a form of learning that collaborates online lectures with face-to-face lectures in class.

\section{ACKNOWLEDGMENT}

Thank you to the respondents (students) for great cooperation and taking the time to fill out the online questionnaire

\section{REFERENCES}

[1] I. K. Sudarsana dkk, COVID-19: Perspektif Pendidikan. Denpasar: Yayasan Kita Menulis, 2020

[2] and S. E. K. W. He, G. Xu, "Online IS Education for the 21st Century,” J. Inf. Syst. Educ., vol. 25, no. 2, p. 101, 2014.

[3] R. R. and S. S. S. Palvia, P. Aeron, P. Gupta, D. Mahapatra, R. Parida, "Online Education: Worldwide Status, Challenges, Trends, and Implications," J. Glob. Inf. Technol. Manag., vol. 21, no. 4, pp. 233-241, 2018, doi: 10.1080/1097198X.2018.1542262.

[4] J. H. and N. A. S. Z. Tasir, Y. M. H. Al-Dhelei, "Students' Perception towards the Use of Social Networking as an e-learning Platform," in In 10th WSEAS International Conference on Education and Educational Technology, Penang: Malaysia, 2011, pp. 70-75.

[5] J. A. N. M. Alqudah, H. Jammal, O. Saleh, Y. Khader, N. Obeidat, "Perception and experience of academic Jordanian ophthalmologists with E-Learning for undergraduate course during the COVID-19 pandemic," Ann. Med. Surg., vol. 59, no. 44-47, 2020, doi: https://doi.org/10.1016/j.amsu.2020.09.014.

[6] and W. D. A. A. Zamista, H. Rahmi, A. Sellyana, "Student Perception of Calculus during Online Learning," J. THEOREMS
(The Orig. Res. Math., vol. 5, no. 1, pp. 41-48, 2020, doi: https://doi.org/10.36835/modeling.v7i2.618.

[7] B. Kusumaningrum and Z. Wijayanto, "Apakah Pembelajaran Matematika Secara Daring Efektif? (Studi Kasus pada Pembelajaran Selama Masa Pandemi Covid-19)," J. Mat. Kreat., vol. 11, no. 2, pp. 139-146, 2020, doi: https://doi.org/10.15294/kreano.v11i2.25029.

[8] A. Sobur, Psikologi Umum dalam Lintasan Sejarah. Bandung: Pustaka Setia, 2013.

[9] A. Sholikhah, "Hubungan Persepsi Terhadap Teknik Statistik dengan Minat Melakukan Penelitian Kuantitatif," J. KOMUNIKA, vol. 11, no. 2, pp. 313-335, doi: 10.24090/KOMUNIKA.V11I2.1372.

[10] and N. R. U. S. Maulah, F. Nurul, "Persepsi Mahasiswa Biologi terhadap Perkuliahan Daring sebagai Sarana pembelajaran selama Pandemi Covid-19," J. Pendidik. Biol. ALVEOLI, vol. 1, no. 2, pp. 49-61, 2020.

[11] Darmadi, Pengembangan Model Dan Mertode Pembelajaran Dalam Dinamika Belajar Siswa. Yogyakarta: DeepPublish, 2017.

[12] H. Manis, Learning Is Easy. Jakarta: Elex Media Komputindo, 2013.

[13] and L. O. A. J. W. S. K. Tulqubra, M. Sudia, "Pengaruh Gaya Belajar dan Persepsi Siswa Mengenai Variasi Mengajar Guru terhadap Hasil Belajar Matematika Siswa," J. Penelit. Pendidik. Mat., vol. 6, no. 3, pp. 113-136, 2018, doi: http://dx.doi.org/10.36709/jppm.v6i3.9144.

[14] and R. P. M. Mulyana, B. H. Rainanto, D. Astrini, "Persepsi Mahasiswa atas Penggunaan Aplikasi Perkuliahan Daring saat Wabah Covid-19," J. Anal. Sist. Pendidik. Tinggi Indones., vol. 4, no. 1, doi: https://doi.org/10.36339/jaspt.v4i1.301.

[15] and N. I. K. A. Azhar, "Effectiveness of Google Classroom: Teachers' Perceptions"," PRIZREN Soc. Sci. J., vol. 2, no. 2, pp. $52-$ 66,2018

[16] and A. R. S. Gon, "Effectivity of e-learning through WhatsApp as a teaching learning tool," MVP J. Med. Sci., vol. 4, no. 1, pp. 19-25, 2017, doi: 10.18311/mvpjms/2017/v4i1/8454.

[17] M. F. Saifuddin, "E-learning dalam persepsi mahasiswa," $J$. Varidika, vol. 29, no. 2, pp. 102-109, 2018, doi: 10.23917/varidika.v29i2.5637. 